\title{
Discovering Lecturers' Perspectives of the Use of 'English for Academic Survival Mobile Learning Module’ (Tutor Me) Among Tertiary Students
}

\author{
Nurizah binti Md Ngadiran $^{1} \&$ Nor Aziah Alias ${ }^{1}$ \\ ${ }^{1}$ Faculty of Education, Universiti Teknologi MARA (UiTM) Puncak Alam Campus, Malaysia \\ Correspondence: Nurizah binti Md Ngadiran, Faculty of Education, Universiti Teknologi MARA (UiTM) \\ Puncak Alam Campus, Malaysia. E-mail: nurizah@uthm.edu.my
}

Received: November 6, 2018

Accepted: December 1, 2018

Online Published: December 28, 2018

doi:10.5539/ass.v15n1p49

URL: https://doi.org/10.5539/ass.v15n1p49

\begin{abstract}
Due to the advancement of mobile technologies, over the past few years, the perceptions relating to mobile learning (mLearning) have been evolving. The purpose of this study was to examine the lecturers' perspectives on the use of 'Tutor Me' by the lecturers of English for Academic Survival (UHB 10302) course during tutorial sessions and independent study hours among tertiary students of Universiti Tun Hussein Onn Malaysia (UTHM). Two lecturers who had used the platform were interviewed by the developer of 'Tutor Me'. The results indicated that the lecturers were positive on the use of 'Tutor Me' as one of the mLearning platform to be used to the students of UHB 10302 course.
\end{abstract}

Keywords: mobile learning, mobile language learning, tertiary-level students

\section{Introduction}

In the context of traditional English as a Second Language (ESL) learning, it is essential for the learners to come to classes and learn from their teachers. However, in the context of mobile learning, known as mLearning, these ESL learners are able to learn any aspects that they are interested in or need without time and location restriction (Sarrab et al., 2014). Thus, the implementation of mLearning in ESL learning has influenced the education field and prompted the development of mobile education and electronic learning (eLearning). Mupfiga et al. (2017) have highlighted that mLearning is the result of the intersection between mobile education and eLearning.

\subsection{Literature Review}

One of the researches examined the pattern in using mobile assisted language learning in four language skills (reading, listening, speaking, and writing) among college ESL instructors in the United States of America (Park \& Slater, 2014). The findings underlined that the teachers believed that they themselves require assistance in understanding the mobile application. By doing so, it will assist language instructors to maximize the benefits of mobile assisted language learning. Chen (2017) had conducted a survey on the perceptions and acceptance on mLearning by university EFL instructors. Looking at the results, the instructors had high levels of perception and acceptance toward mLearning among the learners. At the same time, it can be seen that the younger instructors had higher level of acceptance of mLearning. It was also suggested that these educators utilize mLearning into their classrooms and make mLearning accessible for their students.

These findings managed to grasp the researcher's interest to examine the lecturers' perception on the use of mLearning module (Tutor Me) that was designed in-line with the syllabus of English for Academic Survival (UHB 10302) course. 'Tutor Me' is a platform developed using WP LMS version 2.9.1, a WordPress theme for course management, instructor and student management. The mLearning module can be retrieved at www.aetutorme.com. The primary function of 'Tutor $\mathrm{Me}$ ' is to create a productive teaching and learning environment, inside and outside classroom. Additionally, UHB 10302 lecturers and students can use 'Tutor Me' to conduct collaborative learning.

\subsection{Purpose of the Study}

The purpose of this study is to discover the lecturers' point of views on the use of 'Tutor Me' during tutorial sessions and independent study hours of UHB 10302 course. Their viewpoints were acquired from interview sessions using a set of semi-structured interview questions. The research questions are: 
1) What are the views on the use of mobile technological devices to access 'Tutor Me' among lecturers students?

2) What are the views on the system of 'Tutor Me' among lecturers?

3) What are the views on the learning activities incorporated in 'Tutor Me' among lecturers?

\section{Method}

To obtain the lecturers' opinions towards 'Tutor Me', two (2) lecturers had to answer a set of interview questions face-to-face with the developer of the mLearning module on the strengths and the weaknesses of the mLearning platform. The data was transcribed by the researcher and classified into several themes suggested by Elias (2011), Sayfouri (2016), and Tang (2013). Prior to the interview sessions, the lecturers had to first attend a briefing and training session pertaining to the use of 'Tutor Me' in the process of learning and teaching UHB 10302 course in Special Semester, Session 2017/2018. In the particular session, the developer shared the characteristics of the mLearning module, the pedagogical aspects of the mLearning module and the lecturers' roles and tasks in this research. Following that, the lecturers executed the mLearning platform for five weeks during tutorial sessions and independent study hours of UHB 10302 course.

\section{Results}

\subsection{Findings of Evaluation Phase (Use of 'Tutor Me')}

As previously mentioned, the feedback from the interviews were transcribed and coded into several categories based on themes by Elias (2011), Sayfouri (2016), and Tang (2013). The personal views from lecturers were divided into 'advantages' and 'drawbacks'. Categories that were considered 'advantages' were equitability, flexibility, simplicity, responsibility, intelligibility, dependability, and productivity, while only connectivity was considered 'drawback'.

\subsubsection{Equitability}

Equitability is related to the accessibility of 'Tutor Me'. The lecturers of UHB 10302, via their mobile technological devices, were able to access 'Tutor Me' in many locations. The lecturers accepted the use of smartphones and laptops to access 'Tutor Me'. This platform can be accessed through mobile devices with the Internet connection. As mentioned by the lecturers, all students possessed smartphones and laptops, thus the process of completing tasks via 'Tutor Me' was easier. IS1 implied that using smartphones and laptops to access 'Tutor Me' was acceptable, as most students and lecturers of UTHM owned these mobile devices. Hence, it facilitated the teaching and learning of UHB 10302 via 'Tutor Me'. The respondents also agreed that smartphones and laptops were suitable for teaching and learning.

Example 1: Interview excerpt from a lecturer (IS1) on the use of mobile technological devices in accessing 'Tutor Me'.

Lecturer 2: Based on my own experience during this research, I had used my laptop and smartphone to access 'Tutor Me'. I think most of the students have their own smartphone and laptop as well. When I asked them to complete certain tasks in 'Tutor Me', it seems to me that they were fine with it. I guess because they have the devices with them all the time. Yes, I think, laptops and smartphones are suitable tools for mLearning.

On top of that, the lecturers preferred the concept of learning in a different location. Besides accessing 'Tutor Me' during tutorial sessions in language laboratory, it could also be used during independent study hours outside classroom. Hence, the student could learn in any locations.

Example 2: Interview excerpt from a lecturer (IS2) on learning outside classroom through 'Tutor Me'.

Lecturer 1: For me, the use of mobile devices to teach and learn can be applied in UTHM. Besides language laboratories, the students can easily learn and discuss with me or their course mates anywhere and anytime when they have difficulties. Although 'Tutor Me' has to be accessed with the Internet connection, if I am not mistaken, the students' hostels have free WIFI. However, as you know, most of them have their own broadband or mobile data.

After reviewing the interviews, the lecturers shared their optimistic view about teaching and learning UHB 10302 via 'Tutor Me' outside classroom setting, respectively. They were open with the use of smartphones and laptops in accessing 'Tutor Me'. They also agreed that 'Tutor Me' could be considered as a teaching and learning platform outside classroom. Despite the Internet connectivity problems, most UTHM students and lecturers subscribed to broadband and mobile data services, so it is possible for them to log in 'Tutor Me' regardless of location and time. 


\subsubsection{Flexibility}

According to the lecturers, 'Tutor Me' was considered a flexible platform, as the students were able to learn based on their language abilities and preferences. They were given the opportunities to find relevant information via the Internet for the tasks given by the lecturers and enter the information in the mLearning module. Based on the responses during the interviews, the flexibility of 'Tutor Me' is an important aspect for lecturers and students.

IS3 showed the acceptance of lecturers towards the concept of learning in stages in 'Tutor Me'. Since the exercises could be uploaded on 'Tutor Me', this mLearning platform provided flexibility for the students to finish the tasks.

Example 3: Interview excerpt from a lecturer (IS3) of the concept of learning in stages in 'Tutor Me'.

Lecturer 2: Learning in stages in 'Tutor Me', I think it help the students. They had the chance to familiarise themselves with the topic by doing easy tasks first.

Based on the overall interview findings, the concept of learning in stages via 'Tutor Me' was well-received by the lecturers. According to the lecturers, the students were able to comprehend the subject matters as they would choose to complete easier tasks first. This concept was also consistent with the experts in the development phase.

Apart from that, 'Tutor Me' allowed the students to search for information via the Internet. Based on their observation, they could enter the information in 'Tutor Me', which was not limited to text-based, according to the topics given by their lecturer. They were also permitted to upload graphics and videos. One of the examples was speaking task that required students to get information on student life and responsibilities in university prior to their oral presentation. The developer of 'Tutor Me' explained the steps to upload the information on 'Tutor Me', while the lecturer explained the information needed for the tasks.

Example 4: Interview excerpt from a lecturer (IS4) on student searching for and entering information in 'Tutor Me'.

Lecturer 2: With 'Tutor Me', the students were given opportunities to find and upload information on certain topics. For instance, for the introduction, instead of explaining to them on student's life. Why don't they find info themselves? They used pictures and videos as well. Guidance was provided for the students as well. As a lecturer, I can directly see their submissions.

The interview information from IS4 highlighted that students used other methods to search for and enter information. When using 'Tutor Me', students could enter the information in the platform after they obtained it. Then, the lecturers were able to receive their submissions immediately.

\subsubsection{Simplicity}

Simplicity is part of the WP LMS platform used by the researcher to develop 'Tutor Me'. As mentioned earlier, WP LMS is an open source platform to develop a learning management. It was considered as a manageable platform by the lecturers and students. UHB 10302 lecturers were very optimistic about the mLearning module. They underlined several differences between before and after using 'Tutor Me' for UHB 10302. IS9 posited that the presentation of 'Tutor Me' was well-received by UHB 10302 students and lecturers.

Example 5: Interview excerpt from a lecturer (IS5) on the simplicity of 'Tutor Me' application system.

Lecturer 1: I like to use this learning management system. The reason? It was very easy to use this platform. It will definitely benefit the students in many ways. I also believe that the students love this kind of free platform. They can constantly access the content with no disturbance.

The lecturers of UHB 10302 admitted that they had never heard of WP LMS before 'Tutor Me' was introduced to them. Previously, most lecturers used Edmodo in other courses, which is similar to Facebook. However, they were very optimistic about the implementation of WP LMS as a platform to develop 'Tutor Me'. It is a practical and simple system to teach and learn UHB 10302. IS6 and IS12 stated that 'Tutor Me' management system was easy to be used by UHB 10302 lecturers and students, respectively.

Example 6: Interview excerpt from a lecturer (IS6) on the simplicity of 'Tutor Me' management system.

Lecturer 2: To be honest, this is my first experience using WPLMS. I had used Edmodo previously. Edmodo is quite similar to Facebook, if I'm not mistaken 'Tutor Me' is not that difficult. It is a manageable system and suitable for teaching this course.

\subsubsection{Endurability}

The lecturers had also pointed out the endurability of 'Tutor Me' learning environment on errors. 'Tutor Me' 
provided students with notes, YouTube videos, and downloadable materials on topics related to UHB 10302. With notes and videos, students were able to get information before the exercises and assignments were done, thereby reducing possible errors from students. Below sections delineate explanation of the simplicity of 'Tutor Me' from the lecturers.

The interview analysis showed that the lecturers and students were positive about the availability of the notes for UHB 10302 students. The students needed clarification on topics that were discussed face-to-face. When they had the notes, they did not have to disturb the lecturers. The students were very confident of completing the tasks after reading the notes. IS7 agreed that the notes were well-received by UHB 10302 lecturers and students, respectively.

Example 7: Interview excerpt from a lecturer (IS7) on the ability to read notes via 'Tutor Me'.

Lecturer 1: It is good that there are reading notes in 'Tutor Me'. It helps actually. For example, when the students are not clear with certain things, they can always refer to the notes. Then, they can complete the exercises after that. The notes provided better understandings for the topics in English for Academic Survival.

Besides reading notes, the students may watch YouTube videos to get better understanding about the topics. The videos were chosen by the lecturers according to the syllabus of UHB 10302. The students believed that the videos further aided them to complete the tasks given by the lecturers.

IS8 stressed that the YouTube videos were accepted by UHB 10302 lecturers and students.

Example 8: Interview excerpt from a lecturer (IS8) on the ability of YouTube videos in 'Tutor Me'.

Lecturer 2: The videos from YouTube were selected by the lecturers... The videos... are related to the course outline... syllabus of English for Academic Survival... In my opinion, video helps the students to understand the topic outside classroom. We cannot be around them $24 / 7$ to answer their questions... So, it's good that 'Tutor Me' had all the YouTube videos... The videos had assisted... the students... to comprehend the topics. So, the students can answer the questions with clearer understandings...

The analysis of the interviews highlighted that YouTube videos in 'Tutor Me' could increase the understanding of students on the topics before completing the exercises. Therefore, students were expected to make minimal mistakes in the drills.

The UHB 10302 lecturers were positive about the availability of downloadable learning materials in 'Tutor Me'. Based on the findings in the interview, they outlined some reasons of accepting this learning activity via 'Tutor Me'. One of the reasons was the lecturers could upload relevant materials in the mLearning module that allowed students to download later. Then, students can choose to print out or save the learning materials in the form of softcopy. The students could rely on these materials as guidelines to complete the tasks with less mistakes.

Example 9: Interview excerpt from a lecturer (IS 9) on downloadable learning materials in 'Tutor Me'.

Lecturer 1: I uploaded my notes in 'Tutor Me' so that the notes can be downloaded by the students. They can refer to my materials before completing the exercises or assignments. The students can actually choose to save them or print out the materials.

The analysis of the interview demonstrated that UHB 10302 lecturers agreed with the accessibility of downloadable notes in 'Tutor Me' that students could grasp the topics before completing the exercises with minimal mistakes.

\subsubsection{Sustainability}

From the interview sessions, lecturers were able to maintain their platform usage. They did not have to rely on external technologies to complete the tasks in 'Tutor Me'. The process of completion was efficient because most exercises could be done in 'Tutor Me'. They did not have to convert their answers into word-processing software (such as Microsoft Word) and upload them.

IS10 expressed their view about the sustainability of 'Tutor Me' from a perspective of lecturer and student, respectively.

Example 10: Interview excerpt from a lecturer (IS10) on the sustainability of 'Tutor Me'.

Lecturer 2: Based on my observations, the students liked to do the tasks in 'Tutor Me'. Spaces were provided for them to enter their answers. Students are exposed to advanced technologies. I don't think they will like it if there are so many steps involved. 
Based on the interview data, when students enter their answers in 'Tutor Me', their interest in using the mLearning module could be retained. After steps of using the system were provided, the lecturer also mentioned that the students' exposure to advanced technology allowed them to focus on the exercises.

\subsubsection{Dependability}

Based on the interview responses from lecturers, although 'Tutor Me' promoted self-learning, it also served as a platform for the students to discuss their difficulties in certain tasks. Through forums, should the students have any doubts or questions in regards with the tasks given, the students could post the questions to be answered by the lecturers or fellow course mates. The students, via forums, were guided until they were clear with the explanation given. The students and lecturers felt that this activity assisted the students along the process of learning UHB 10302.

IS11 expressed his view on the dependability aspect of 'Tutor Me' from a perspective of a lecturer.

Example 11: Interview excerpt from a lecturer (IS11) on the dependability aspect of 'Tutor Me'.

Lecturer 2: I used forums in 'Tutor Me' to guide my students. If they have any questions, simple, they just posted them in forum and I posted my answers. The course mates could also help them. Of course, I observed the discussion sessions. I personally think that forum is suitable as a discussion platform between students and me in 'Tutor Me'.

The lecturer (IS11) emphasised forum was an appropriate discussion platform. The lecturer also mentioned that the students were allowed to post their questions on forum that would be replied by other students or the lecturer. At the same time, the lecturer would observe the discussion session.

\subsubsection{Productivity}

Lecturers underlined the aspect of productivity as an advantage of using 'Tutor Me'. This mLearning platformwould give notifications to students about the assignments that had successfully prompted responses from them in several ways. IS12 on the productivity aspect of 'Tutor Me' from a perspective of a lecturer.

Example 12: Interview excerpt from a lecturer (IS12) on the productivity aspect of 'Tutor Me'.

Lecturer 1: Before this, I asked the students to submit the hardcopy of their assignments in front of my room. But, some of the students did not submit them. Their reasons? They had forgotten about the submission dates! And some of the students did not manage to find my room and other reasons. After introducing 'Tutor Me', for me, I am quite satisfied. The assignment was uploaded on 'Tutor Me', Then, the submission date and reminders were set. The students were reminded on the dues and they were able to upload their answers in 'Tutor Me'. Again, hassle-free, which is good!

The lecturer (IS12) stated that the assignments were uploaded on 'Tutor Me'. Then, reminders on the submission date was also set in the system. Before deadline, students would receive notifications as reminders. They could also upload their answers on the mLearning mobile module directly.

\section{Discussion}

In general, the lecturers were rather pleased with several aspects of 'Tutor Me'. Looking at equitability, which concerns accessibility of 'Tutor Me', users have confirmed its availability through their mobile devices. Besides that, the mLearning module can be logged-in from a few locations. These findings are similar to Hashim et al. (2017) that stated mobile devices are beneficial tools for a number of mLearning activities.

During interview sessions, lecturers discussed about how they managed to sustain and maintain their focus while using the platform. It was because they did not have to rely on external assistive technologies to complete tasks in 'Tutor Me'. In regard to this, Al-Adwan et al. (2013) and Stockwell (2013) have stated that students' level of motivation to learn can be sustained and increased using user-friendly technologies. Thus, simplicity was the key to utilise WP LMS as the platform to develop "Tutor Me". WP LMS is an open source platform to develop learning management systems. In this research, lecturers considered this platform as a manageable and hassle-free learning platform for UHB 10302.

Besides that, lecturers deliberated on endurability aspect of "Tutor Me" learning environments on errors. Via "Tutor Me", UHB 10302 students were provided with notes to be read, YouTube videos to be watched, and materials on highlighted topics to be downloaded. Through notes and videos, students could get information to complete exercises and assignments. Hence, possibilities to make errors might be reduced.

As for dependability, based on feedback from the lecturers in the interview sessions, although 'Tutor Me' promoted self-learning among students, had also provided a discussion platform for them. This platform, in the 
form of forum, allowed students to discuss difficulties in understanding or completing certain tasks. In addition, lecturer underlined productivity as one of the advantages of using "Tutor Me". Through this mLearning platform, students received reminders set by lecturers and the system itself for assignments and tasks. Therefore, lecturers felt that these reminders had successfully produced responses from students in several ways.

\section{Conclusion}

The findings of the evaluation phase were obtained from semi-structured interviews, which were conducted with two lecturers of UHB 10302 who had used 'Tutor Me'. The interviews were recorded using video camera recorder for references. The evaluation were done according to the suggestions by Elias (2011), Sayfouri (2016), and Tang (2013). The findings answered the following research questions:

1) What are the views on the use of mobile technological devices to access 'Tutor Me' among lecturers students?

2) What are the views on the system of 'Tutor Me' among lecturers?

3) What are the views on the learning activities incorporated in 'Tutor Me' among lecturers?

To recapitulate on the findings of the interviews, the lecturers used smartphones and laptops to access the mLearning module in UTHM. They agreed that 'Tutor Me', developed using WP LMS, was user-friendly and easy. Although they had experienced minor difficulties at the beginning, they were able to grasp the essence of the system after they were given training and explanation by the researcher. Moreover, the lecturers were open with the idea of learning UHB 10302 regardless of place and time via 'Tutor Me'. According to the lecturers, students could also keep their interest in completing the tasks in 'Tutor Me' since they could enter their answers in the system without relying on other software. Given that 'Tutor Me' required Internet connection to function, the lecturers subscribed to broadband and mobile data services for them to log in the mLearning mobile module without disappointment.

\section{References}

Al-Adwan, A., Al-Adwan, A., \& Smedley, J. (2013). Exploring students acceptance of e-learning using Technology Acceptance Model in Jordanian universities. International Journal of Education and Development using Information and Communication Technology, 9(2), 4.

Chen, K. T. C. (2017). Examining EFL instructors' and students' perceptions and acceptance toward M-learning in higher education. Universal Access in the Information Society, 16(4), 967-976.

Elias, T. (2011). Universal instructional design principles for mobile learning. The International Review of Research in Open and Distributed Learning, 12(2), 143-156.

Hashim, H., Yunus, M. M., Embi, M. A., \& Ozir, N. A. M. (2017). Mobile-assisted Language Learning (MALL) for ESL Learners: A Review of Affordances and Constraints. Sains Humanika, 9(1-5).

Lyashenko, M. S., \& Malinina, I. A. (2015). The Use of Learning Management System projects for teaching a foreign language in the university. Procedia-Social and Behavioral Sciences, 182, 81-88.

Mupfiga, P., Mupfiga, M. C., \& Zhou, T. G. (2017). Enhancing Teaching and Learning through the Use of Mobile Technologies in Zimbabwean Universities. Journal of Systems Integration, 8(2), 43.

Tang, J. (2013). The Research on Blended Learning of ESL Based on Moodle Platform. Studies in Literature and Language, 6(2), 30 .

Sarrab, M., Alzahrani, A., Alwan, N. A., \& Alfarraj, O. (2014). From traditional learning into mobile learning in education at the university level: undergraduate students perspective. International Journal of Mobile Learning and Organisation, 8(3-4), 167-186.

Sayfouri, N. (2016). Evaluation of the learning management system using students' perceptions. Medical journal of the Islamic Republic of Iran, 30, 460.

Stockwell, G. (2013). Technology and motivation in English-language teaching and learning. In International perspectives on motivation (pp. 156-175). Palgrave Macmillan UK.

\section{Copyrights}

Copyright for this article is retained by the author(s), with first publication rights granted to the journal.

This is an open-access article distributed under the terms and conditions of the Creative Commons Attribution license (http://creativecommons.org/licenses/by/4.0/). 